\title{
RANCANG BANGUN ALAT MOUNTING DAN DISMOUNTING BEARING DENGAN MENGGUNAKAN HYDRAULIC JACK
}

\author{
Ulia Ridhani $^{1 *}$, Aminuddin², Riky Susanto ${ }^{3}$, Adhim Abdul Jabbar ${ }^{4}$ \\ ${ }^{1,2,3,4}$ Perawatan dan Perbaikan Mesin, Politeknik Bosowa \\ *e-mail: uliaridhani@yahoo.com
}

\begin{abstract}
This research aims to design tools that work with multifunctional that can mounting and dismounting bearing using a hydraulic jack. This tool facilitates the work of everyone when will do the job to mounting and dismounting bearing. This study is carried out because there are many people who mounting and dismounting bearing improper. Eg mounting bearings by grinding outer bearing and dismounting bearing by pulling or hitting its outer part. This will impact on bearing service life. However, as these habits are hard to change considering everyone has a different way of working. The results showed that the tool mounting and dismounting bearings can install and remove the bearing securely and easily. The time needed to mounting bearing 50.2 to 67.9 seconds. As for the dismounting bearing is 71.8 to 75.8 seconds.
\end{abstract}

Keywords : Bearing, Hydraulic Jack, Mounting, Dismounting

\begin{abstract}
Abstrak
Penelitian ini bertujuan untuk merancang alat yang bekerja dengan multifungsi yaitu dapat membuka dan memasang bearing dengan menggunakan hydraulic jack. Alat ini memudahkan pekerjaan setiap orang ketika akan melakukan pekerjaan memasang dan melepas bearing. Penelitian ini dilakukan mengingat saat ini masih banyak orang yang memasang dan melepas bearing yang tidak tepat.Misalnya memasang bearing dengan cara menumbuk outer bearing dan melepas bearing dengan cara menarik atau memukul bagian outer-nya. Hal tersebut akan berdampak pada umur pakai bearing.Meski demikian, kebiasaan seperti ini sulit untuk diubah mengingat setiap orang memiliki cara kerja yang berbeda. Hasil penelitian menunjukkan bahwaalat mounting dan dismounting bearing dapat memasang dan melepas bearing dengan aman dan mudah. Waktu yang dibutuhkan untuk memasang bearing (mounting) 50,2 - 67,9 detik. Sedangkan untuk melepas bearing (dismounting) adalah 71,8-75,8 detik.
\end{abstract}

Kata kunci: Bearing, Hydraulic Jack, Melepas,Memasang

\section{Pendahuluan}

Berlangsungnya kelancaran proses produksi disebuah industri tidak lepas dari berbagai peralatan pendukung yang bekerja dengan baik. Tetapi peralatan yang bekerja secara continue sewaktuwaktu dapat mengalami kerusakan pada komponen tertentu.

Untuk meminimalisir kerusakan yang terjadi pada peralatan, divisi maintenance harus bekerja dengan baik dengan cara menerapkan preventive maintenance. Jika cara ini dilakukan dengan teratur, maka secara efektif dapat mencegah terjadinya kerusakan.
Bearing merupakan salah satu komponen mesin yang kurang menjadi perhatian khusus dibeberapa industri. Bearingadalah suatu elemen mesin yang berfungsi mengurangi gesekan yang terjadi diantara bagian mesin yang berputar dengan yang diam. Kerusakan pada bearingdisebabkan beberapa faktor, diantaranya kesalahan memasang dan melepas bearing dari poros. Pada saat memasang dan melepas bearing dibutuhkan banyak peralatan khusus sehingga harus mengganti peralatan, begitu pula dengan waktu yang cukup lama dibutuhkan untuk memasang atau melepas bearing. Oleh karena itu, 
Penelitian ini membuat sebuah alat prototipe dengan keunggulan yang mampu bekerja sebagai alat mounting dan dismounting bearing, menjadikan alat ini memudahkan pekerjaan pada saat akan memasang dan melepas bearing dengan menggunakan hydraulic jack yang dirancang dengan mekanisme kerja pusher dan puller.

\section{Metoda Penelitian}

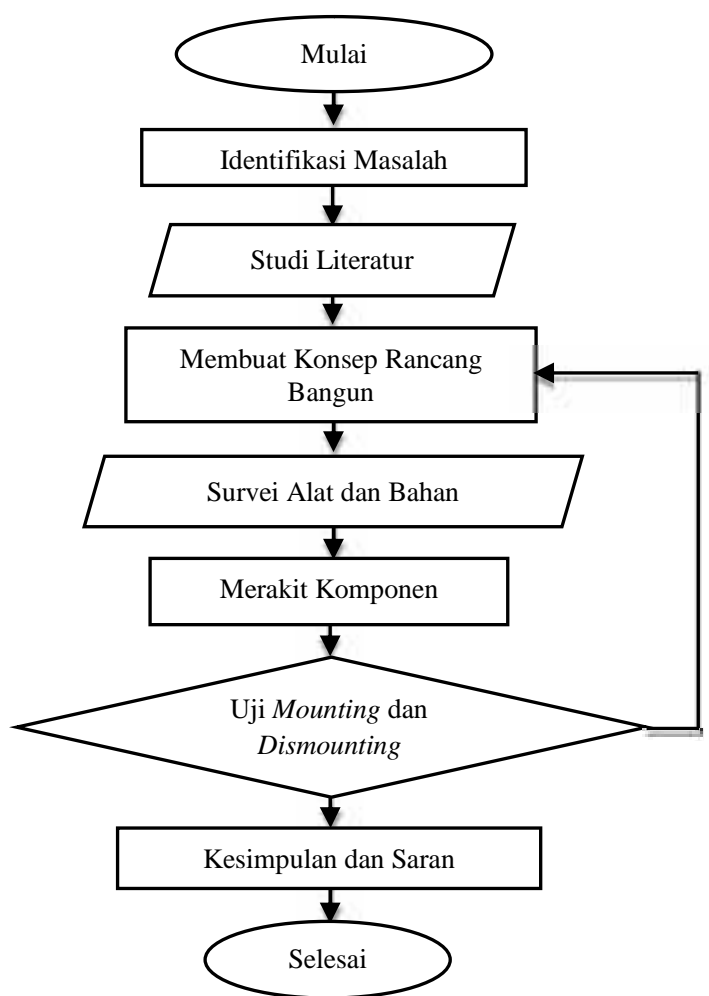

Gambar 1. Diagram Alir Penelitian

\subsection{Roadmap Penelitian}

Penelitian ini tidak terlepas dari hasil penelitian-penelitian terdahulu yang pernah dilakukan sebagai bahan perbandingan dan kajian. Penelitian ini juga relevan dengan alat yang dibuat. Berikut disajikan penelitian-penelitian tersebut:

1. Rancangan alat yang digunakan untuk membantu proses pelonggaran dan pengencangan baut pada roda ban mobil kendaraan berat yang membutuhkan nilai torsi yang tinggi dengan memanfaatkan hydraulic jack.
Tujuan dari penelitian ini adalah untuk memudahkan proses pelonggaran dan pengencangan ban mobil kendaraan berat serta mengurangi tenaga dan waktu ketika terjadi kerusakan seperti ban meletus atau sejenisnya. Alat ini digunakan bersama dengan kunci pas untuk ban dan hydraulic jack[1].

2. Alat remote control yang digunakan bersama dengan hydraulic jack. Seperti yang diketahui bahwa hydraulic jack memiliki beberapa kelemahan seperti membutuhkan lebih banyak energi untuk beroperasi, tidak cocok untuk wanita dan tidak dapat digunakan pada permukaan yang tidak rata. Sehingga dibuatlah sebuah rancangan sistem remote control untuk hydraulic jack yang bertujuan untuk mempermudah, menghemat waktu dan energi pada saat menggunakan hydraulic jack[2].

3. "Design and Fabrication of Hydraulic Bearing Puller" yaitu sebuah alat pelepas bearing (dismounting) dari poros dengan menggunakan hydraulic jack. Alat ini mudah dioperasikan dan siapa saja bisa mengoperasikannya. Hydraulic jack digunakan sebagai komponen utama yang menjadi alat penarik bearing dari poros. Poros dan bearing, masing-masing akan dipegang oleh sebuah alat pencekam selama proses pelepasan dilakukan[3].

4. "Design And Fabrication Of Hydraulic Bearing Puller and Pusher" dalam penelitiannya tentang sebuah alat prototipe yang berfungsi sebagai alat pemasang (mounting) dan pelepas (dismounting) bearing. Alat tersebut bekerja dengan mekanisme hydraulic jack. Penelitian tersebut dilakukan untuk memudahkan pekerjaan dalam memasang dan melepas bearing[4]. 


\subsection{Konsep Rancangan}

Perancangan rangka mounting dan dismountingbearing diadopsi dari bentuk shop press seperti yang beredar di tokotoko penjualan shop press. Ada 5 perancangan yang dilakukan seperti ditampilkan pada tabel 1 .

Tabel 1. Konsep Perancangan Alat

\begin{tabular}{|c|c|c|}
\hline No & Perancangan & Keterangan Bahan \\
\hline 1 & Tiang rangka & $\begin{array}{l}\text { Profil UNP } 120 \\
\text { ST37 (55x } 7.0 \times 6) \\
\text { dengan panjang } \\
\text { 1500mm sebanyak } \\
\text { dua batang }\end{array}$ \\
\hline 2 & Penopang atas & $\begin{array}{l}\text { profil UNP } 120 \\
\text { ST37 (55x } 7.0 \times 6) \\
\text { dengan panjang } 700 \\
\text { mm sebanyak dua } \\
\text { batang }\end{array}$ \\
\hline 3 & Kaki rangka & $\begin{array}{l}\text { profil L } 7 \text { x } 7 \text { ST37 } \\
\text { dengan panjang } \\
600 \mathrm{~mm} \text { sebanyak } \\
\text { dua batang dan kaki } \\
\text { tengah dengan } \\
\text { panjang } 580 \mathrm{~mm}\end{array}$ \\
\hline 4 & $\begin{array}{l}\text { Dudukan } \\
\text { hydroulic jack }\end{array}$ & $\begin{array}{l}\text { profil UNP } 120 \\
\text { ST37 (55x 7.0x6) } \\
\text { dengan panjang } \\
590 \mathrm{~mm}\end{array}$ \\
\hline 5 & $\begin{array}{l}\text { Dudukan } \\
\text { penyangga }\end{array}$ & $\begin{array}{l}\text { Profil UNP 120 } \\
\text { ST37 (55x 7.0x6) } \\
\text { dengan panjang } \\
\text { 700mm sebanyak } \\
\text { dua batang }\end{array}$ \\
\hline
\end{tabular}

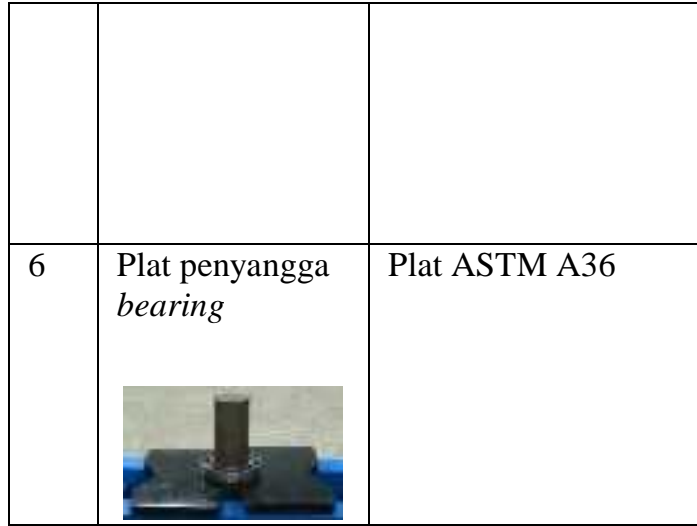

\section{Prinsip Kerja Alat}

Ketika hydraulic jack dioperasikan maka poros yang berada dibawah dudukan hydraulic jack menekan poros yang berada pada plat penyangga. Hal ini disebabkan oleh gaya tekanan dari hydraulic jack yang dioperasikan.

\section{Hasil Penelitian}

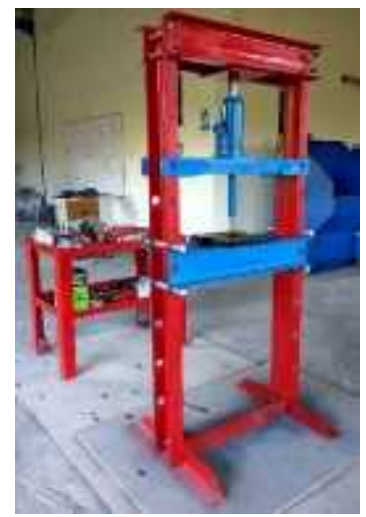

Gambar 2. Alat Mounting dan

DismountingBearing

\subsection{Pengujian Alat Mounting dan Dismounting Bearing}

Pengujian alat ini dilakukan sebanyak tiga kali dengan bearing yang berbeda jenis. Waktu pengaturan awal adalah waktu pada saat penyetelan penyesuaian posisi pin penyangga dengan posisi shaft. Waktu proses adalah waktu penarikan dan pemasangan bearing dari shaft-nya. Sedangkan waktu pengaturan akhir adalah waktu yang dibutuhkan untuk memindahkan bearing dan shaft dari penyangga. 
Tabel 2. Pengujian Mounting Bearing

\begin{tabular}{|c|c|c|c|c|c|}
\hline \multirow[b]{2}{*}{ No } & \multirow[b]{2}{*}{ denis cearng } & \multicolumn{4}{|c|}{ 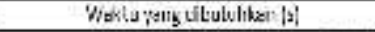 } \\
\hline & & $\begin{array}{l}\text { Herngaturan } \\
\text { atval is: }\end{array}$ & $\begin{array}{c}\text { Hoses } \\
|5|\end{array}$ & $\begin{array}{l}\text { Hernaturan } \\
\text { iktele } / 51\end{array}$ & $\begin{array}{c}\text { Total } \\
\text { valbi } \\
|\mathrm{s}|\end{array}$ \\
\hline 1 & Srifainpasn init'frany & से, & 283 & a & $6 n ; 4$ \\
\hline 2 & Solevea' raller beatis & 24,3 & 10,2 & 4 & 703 \\
\hline 3 & $\begin{array}{l}\text { Single mu riben tronis } \\
\text { hol' bearing }\end{array}$ & $2 \dot{c}, 2$ & 23,9 & 4 & 5,2 \\
\hline
\end{tabular}

Tabel 3. Pengujian Dismounting Bearing

\begin{tabular}{|c|c|c|c|c|c|}
\hline \multirow[b]{2}{*}{ Non } & \multirow[b]{2}{*}{ ento tipary } & \multicolumn{4}{|c|}{ Waktuyarg dtutuhkan $\langle$ ! ! } \\
\hline & & $\begin{array}{l}\text { Fenget.ren } \\
\text { 4wal ;i5 }\end{array}$ & $\begin{array}{l}\text { Froses } \\
\text { isi }\end{array}$ & $\begin{array}{l}\text { Pengat.ren } \\
\text { 4htiris' }\end{array}$ & $\begin{array}{c}\text { Iotal } \\
\text { wakt. } \\
\text { [4 }\end{array}$ \\
\hline 1 & 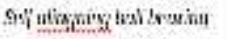 & 23,5 & $4 n, 2$ & 5 & 73,8 \\
\hline 2 & Soherca' roiler centhy & 24,9 & 42,5 & 4 & 72,7 \\
\hline 3 & $\begin{array}{l}\text { Shyle row deep grove bol } \\
\text { Isuring }\end{array}$ & 25,7 & 46,3 & 5 & 71,2 \\
\hline
\end{tabular}

Tabel 2 menunjukkan bahwa ada 3 jenis bearing yang digunakan untuk pengujian alat. Total waktu pemasangan bearing berkisar 50,2 - 67,9 detik. Tabel 3 memperlihatkan waktu yang dibutuhkan untuk melepas bearing. Kisaran waktunya 71,8-75,8 detik.

\section{Kesimpulan}

Dari hasil pembuatan rancang bangun alat mounting dan dismounting bearing dengan menggunakan hydraulic jack disimpulkan bahwa alat mounting dan dismounting bearing dapat memasang dan melepas bearing dengan aman dan mudah. Waktu yang dibutuhkan untuk memasang bearing (mounting) 50,2 - 67,9 detik. Sedangkan untuk melepas bearing(dismounting) adalah 71,8-75,8 detik.

\section{Saran}

Penelitian lanjutan memasang dan melepas bearing dapat dikembangkan dengan menggunakan bearing separator.

\section{Daftar Pustaka}

[1] Ahmad Farudzi Bin Azib, Mohd Sobri Bin Hussien, \& Shamsuddin Bin Abdullah. (2014, January). The Extension Hydraulic Wheel Wrench. International Journal of Applied Science and Technology, 4, 136-146. Retrieved from www.ijastnet.com

[2] Asonye G.U, Nnamani C.E, \& Alaka,C. A. (2015, October). Design And Fabrication Of A Remote Controlled System For A Hydraulic Jack. International Research Journal of Engineering and Technology, 02(07), 1223-1236. Retrieved from www.irjet.net

[3] L.Sanjitkumaran. (2015, October 14). Design And Fabrication Of Hydraulic Bearing Puller. CI Journal of Basic Science and Applied Research, 1(1), 4146.

[4] Rakesh Y. Suryawanshi, Pranay S. Ramteke, Niraj Patil, \& Deepak Kumar. (2015, April). Design and Fabrication of Hydraulic Bearing Puller and Pusher. International Journal for Innovative Research in Science \& Technology, 1(11), 152-156. 